\title{
Be unafraid ... to try something new or challenging
}

\author{
Adam T. Woolley ${ }^{1}$ \\ Published online: 14 September 2018 \\ (C) Springer-Verlag GmbH Germany, part of Springer Nature 2018
}

I have fond memories of 1986. A favorite movie, "Ferris Bueller's Day Off", and song (still on my playlist), "Sledgehammer," are both from 1986. That summer, I also received the scores on three Advanced Placement (AP) Exams I took. By way of explanation, in the United States secondary (high school) students can take standardized tests (AP Exams) on various topics at the end of the school year; they are scored on an integer scale from 1 to 5 , with 5 being the highest; scores of 3 or higher usually qualify the student for course credit at a university. Thus, it was ironic that the score that brought me the most happiness wasn't the 5 that I got on the Chemistry Exam; instead, it was the 3 that I got on the English Exam. My justbarely-passing score of 3 gave me credit for the dreaded freshman writing course, so I would never ever again have to take another English class. That's an "interesting" perspective on writing coming from a future editor.

So, how did I go from having a deep fear of writing to having a successful career where writing is perhaps the most important thing I do? I had to overcome my fear and gain confidence in my ability to succeed in doing new things. As I started my junior year of undergraduate studies, I began to wonder about my fear of writing. The next semester, I chose to confront that fear head-on: I enrolled in a class for English Majors-on the topic of feminist literature. I loved that class; I learned that I could analyze literature effectively, and that I was actually a pretty good writer. When the semester came to an end, I had earned an A!

Adam T. Woolley

woolley-abc-editor@byu.edu

1 Chemistry and Biochemistry Department, Brigham Young University, Provo 84602-5700, USA
A key thing I learned from this experience was to have confidence in confronting new, and seemingly daunting, challenges. This is a great lesson for life in general, but it's especially something that scientists, including analytical chemists, can put in practice. For example, if you work in a mass spectrometry group, but you need some electrochemical data to respond to the review of your manuscript, learn about electrochemistry. Talk to an electrochemist about your research, find the right textbook, and expand your knowledge in this field. If you're a scientist just embarking on an independent career, and you get an intriguing research result that's at or over the edge of your current knowledge, expand your expertise. And don't stress about the time you think it might take to get up to speed; it's truly an investment in your future. If you're a senior researcher in a discipline that's becoming "mature", seek out new research frontiers where you can contribute. And don't worry about a possible, temporary decrease in your publication rate; you're building a foundation for future increased productivity.

Having confidence as you attempt novel or complex things can help you professionally; notably, two of our principal goals as scientists are to generate new information and to provide solutions to challenging problems. (That's also what we seek to publish in ABC, "...novel measurement platforms and their characterization..." and "...multidisciplinary approaches that effectively address 
important scientific problems..." ABC-Aims and Scope). So, fear not, and be confident in confronting some difficult or new scientific problem!

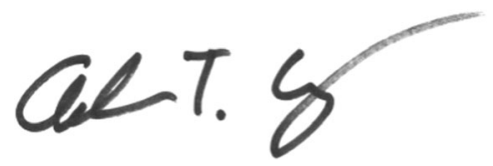

Adam T. Woolley

Chair Editor, ABC

woolley-abc-editor@byu.edu

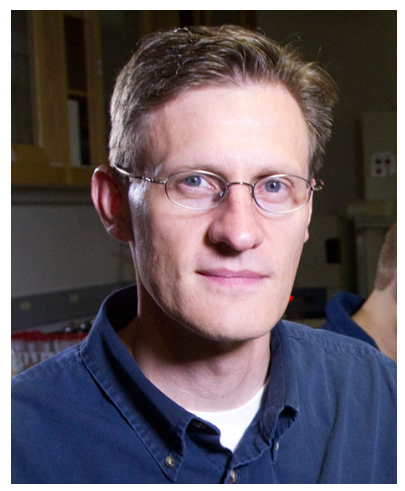

Adam T. Woolley is Chair Editor of Analytical and Bioanalytical Chemistry, and University Professor in the Department of Chemistry and Biochemistry at Brigham Young University in Provo, Utah, USA. His current research focuses on 3D printed integrated microfluidics for biomarker measurement, analytical systems for the identification of bacteria and antibiotic resistance genes in sepsis, and biotemplated fabrication of nanoelectronics. 